\title{
The Effect of Learning Strategy and Creative Thinking on Information Communication and Technology (ICT) Learning Outcomes
}

\author{
Resien 1) \\ Senior High School \\ Methodist Tanjung Morawa-Indonesia \\ resien.chiu@gmail.com
}

\begin{abstract}
The objectives of this research was to determine the effect of learning strategies (blended learning and expository learning) and creative thinking on information communication and technology (ICT) outcomes. This research conducted at SMA Methodist Tanjung Morawa, North Sumatera during September to November 2016, and used a quasi-experimental method with a $2 \times 2$ factorial treatment by level design. The participants were 32 students were devided into two treatment classes. Data analysis of variance (ANOVA) with significance level 0,05 . The result indicate that : student's ICT outcomes who uses blended learning is better than expository learning; there is an interaction between learning strategy and creative thinking; student's ICT outcomes who uses blended learning is higher than expository learning to the student group of higher creative thinking; and student's ICT outcomes who uses blended learning is lower than espository learning to the student group of lower creative thinking.
\end{abstract}

Keywords - blended learning, expository learning, creative thinking, information technology and communication.

\section{Introduction}

The improvement of quality is the most strategic planning in order to improve human resources, so that they have deep knowledge, skills and good attitude which were oriented to knowledge and technology, professional ability and working productivity based on the needs of developing the nations. With those characteristics of human resources quality; thus, that Indonesian country can compete in the world globalizations era for today and in the future. At glance, we can see how the quality of Education in Indonesia that still in low ranges. This condition might reflect from Human Development Index, In Indonesia we called it IPM $^{[1]}$. That positioning Indonesia at Rank 121 on 2013, grow 3 (Three) points from rank 124 in 2012, or down 13 (thirteen) points from rank 108 in 2005. The growth rank IPM in 2013 caused by the improvement and equal spread of the ability from citizen on these three years before. The development of education was more oriented on widen its education; which was had low contribution in achieve the IPM.

Trilling dan Fadel $^{[2]}$ has described that the ability of skills to face the changes on 21 century, that the first (1) learning skills and innovation, that consists of critical thinking and problem solving, communication and collaboration, creativitiu and innovation; the second (2) digital era skills (information, media, and technology) which were know how the information literacy, media literacy and ICT literacy; and (3) career and life skills which consists of flexibility and adaptability, initiative and self direction, social and cross cultural interaction, productivity and accountability, and leadership and responsibility.

ICT subject is one of the subjects in national study system curriculum in 2006 that called in Indonesia Kurikulum Tingkat Satuan Pendidikan (KTSP). Rapidly, the development of technology in many aspects of life today, actually this subject has introduced and practiced of students so fast. In order to face the fast changes that is why we need the ability and want to learn fast on the entire of life. The results of information and technology can help the human to learn fast. Not only, from daily activities, information and technology can use to learning process which is finally can adapted to students in job environment.

The result of observation on the students of SMA Methodist Tanjung Morawa in learning ICT at class, found that there were obstacles in understanding the material by the teachers. The real obstacles are, when learning process happened, teachers give the material to the students by describing it; and then the students will write the important points and after that they will go to the media room (Computer) to practice the material that has given last week. When the process is going on, all the students will do some exercises. In this condition, students that have good concentration and willing to learn will give their good attention to the teachers, but for students that have not motivation in learning will get boring soon. From this situation will derive one group of students that discuss in outside of the material Information technology and communication.

Learning strategy which will be tested of its effectiveness is learning strategy blended learning and learning strategy expository. Learning strategy blended learning is kind of strategy that makes combination of learning in face to face, with online learning fitted with the students' characteristics and its material of information and technology. Thorne ${ }^{[3]}$ described blended learning as "a way of meeting the challenges of tailoring learning and development to the needs of individuals by integrating the innovative and technological advances offered by online learning with the interaction and participation offered in the best of traditional learning". 
Learning strategy expository is a strategy that focused on the process in transferring the learning to the students and generally with describing method. This learning strategy positioning the teachers as the one sources of learning (teacher centered). Joyce, Weil and Calhoun $^{[4]}$ said that expository learning are "“......direct instruction has been use by researchers to refer to a pattern of teaching that consists of teachers's explaining a new concept or skill to students, having them test their understanding by practicing under teacher direction and encouraging them to continue to practice under teacher guidance."

In ICT subject, creative thinking is the most important to achieve the students' goals in learning. And also to measure how long the students can cover the learning process in order to actualize by practicing and producing one useful thing in learning goals.

Creative thinking is one kind of mindset, that trying to discover the new relationship, getting the answer, new method to face the problems, or to produce one type of new arts. Creative thinking engages response or new ideas; Solving the problems in realistic way and defense the originality. MacKinnon ${ }^{[5]}$ stated that have three important terms by creative thinking that, the first (1) get the new responses and ideas; second (2) can solve the problems realistic; and the third (3) defenses the insight originally. So finally, creative thinking is one type of process that used to get the new ideas.

That is why; this research took about the learning process that used blended learning strategy by expository strategy which is used by the teachers with creative thinking of the students to improve learning outcomes of ICT material.

\section{Research Method}

This research using equation experiment method with $(2 \times 2)$ design of factorial. The variables of this research consist of; first (1) dependent variable that is learning outcomes ICT; second (2) independent variables that is treatment (A1: blended learning strategy and A2: expository learning strategy; and (3) attributable variable (B1) high creative thinking and B2 low creative thinking.

Population of this research is all the students in Senior High School Methodist Tanjung Morawa counted 217 students. Samples of this research have chosen on XI class by purposive sampling method, with assumption that $\mathrm{X}$ class is not studying in ICT. Meanwhile XII class did not allowed because will face the final national examination. Getting fixed both of experiment' and control class divided into 30 students each of the class. But, in getting fixed the students with high and low creative thinking for each class by using 'Creativity Instrument Test' figured that adapted from Torrance "Circles Test", and for 10-18 years old only, by psychology faculty University of Indonesia. This indicators consists of the first (1) good flow of thinking; (2) flexibility of thinking; (3) elaboration and the last; and (4) Original ideas. To choose the students that have high and low creative thinking based on the result of figural test. 8 students per group $(30 \times 27 \%)$ stated as group that have high style of thinking and the other group that consist of 8 students too $(30 \times 27 \%)$ stated as group that have low style of thinking. So, the total of all samples are 32 students.
Hypothesis test run with variance analysis (ANOVA) two ways with $2 \times 2$ designs of factorial. Further test will be run with Tukey test ${ }^{[7]}$. Before start with hypothesis test, done with some requirements test which are consisting of: (1) normality test; (2) homogeneity test; (3) linearity regression test ${ }^{[8]}$; (4) significance test of regression; and (5) line alignment test $^{[9]}$.

\section{The Results of Research}

Statistic Descriptive analysis data of the result from this research shown as below on Table 1.

Table 1 The Result of Statistic Descriptive analysis data

Descriptive Statistics

Dependent Variable: HB

\begin{tabular}{llccr}
\hline Strategy & $\begin{array}{c}\text { Creative } \\
\text { Thinking }\end{array}$ & Mean & $\begin{array}{c}\text { Std. } \\
\text { Deviation }\end{array}$ & N \\
\hline \multirow{3}{*}{ BL } & High & 86.30 & 7.45 & 8 \\
& Low & 64.65 & 5.86 & 8 \\
& Total & $\mathbf{7 5 . 4 8}$ & $\mathbf{1 2 . 9 1}$ & $\mathbf{1 6}$ \\
\hline \multirow{3}{*}{ Expository } & High & 72.42 & 9.63 & 8 \\
& Low & 65.76 & 10.80 & 8 \\
& Total & $\mathbf{6 9 . 0 9}$ & $\mathbf{1 0 . 4 7}$ & $\mathbf{1 6}$ \\
\hline \multirow{3}{*}{ Total } & High & 79.36 & 10.98 & 16 \\
& Low & 65.21 & 8.41 & 16 \\
& Total & $\mathbf{7 2 . 2 8}$ & $\mathbf{1 2 . 0 1}$ & $\mathbf{3 2}$ \\
\hline
\end{tabular}

Hypothesis test in this research connected with: the first (1) Main effect, which is both of blended learning strategy (A1) and expository learning strategy (A2) and high creative thinking (B1) and low creative thinking (B2); the second (2) Interaction effects, which is both of high creativity of thinking and the third (3) simple effects. The results of calculations with ANOVA are presented in Table 2.

\section{Table 2 Hypothesis test summary with ANOVA}

Tests of Between-Subjects Effects

Dependent Variable: HB

\begin{tabular}{lrrrrr}
\hline \multicolumn{1}{c}{ Source } & $\begin{array}{c}\text { Type III } \\
\text { Sum of } \\
\text { Squares }\end{array}$ & df & $\begin{array}{c}\text { Mean } \\
\text { Square }\end{array}$ & F & Sig. \\
\hline $\begin{array}{l}\text { Corrected } \\
\text { Model }\end{array}$ & $2377.33^{\mathrm{a}}$ & 3 & 792.44 & 10.581 & .000 \\
Intercept & 167221.22 & 1 & 167221 & 2232.77 & .000 \\
Strategy & 325.89 & 1 & 325.89 & $\mathbf{4 . 3 5 1}$ & $\mathbf{. 0 4 6}$ \\
Creative & 1602.34 & 1 & 1602.34 & 21.395 & .000 \\
Strategy* & 449.10 & 1 & 449.10 & $\mathbf{5 . 9 9 6}$ & $\mathbf{. 0 2 1}$ \\
Creative & 2097.03 & 28 & 74.89 & & \\
Error & 171695.59 & 32 & & & \\
Total & 4474.37 & 31 & & & \\
Corrected Total & 44.31 & & & & \\
\hline
\end{tabular}

a. R Squared $=.531($ Adjusted R Squared $=.481)$

Based on hypothesis calculation, shown there were interaction between learning strategy and creative thinking. Then performed further test with Tukey test that shown on table 3 . 
Table 3 Summaries of Tukey test.

\begin{tabular}{ccrrr}
$\begin{array}{l}\text { Multiple Comparisons } \\
\text { Dependent Variable: HB } \\
\text { Tukey HSD }\end{array}$ & & & \\
\hline $\begin{array}{c}\text { (I) } \\
\text { Interaction }\end{array}$ & $\begin{array}{c}\text { (J) } \\
\text { Interaction }\end{array}$ & $\begin{array}{c}\text { Mean } \\
\text { Difference } \\
\text { (I-J) }\end{array}$ & $\begin{array}{c}\text { Std. } \\
\text { Error }\end{array}$ & Sig. \\
\hline \multirow{3}{*}{$\mathbf{A 1 B 1}$} & A1B2 & $\mathbf{2 1 . 6 4 5 0}$ & $\mathbf{4 . 3 2 7}$ & $\mathbf{0 . 0 0 0}$ \\
& A2B1 & $\mathbf{1 3 . 8 7 5 0}^{*}$ & $\mathbf{4 . 3 2 7}$ & $\mathbf{0 . 0 1 7}$ \\
& A2B2 & $20.5350^{*}$ & 4.327 & 0.000 \\
\hline \multirow{3}{*}{$\mathbf{A 1 B 2}$} & A1B1 & $-21.6450^{*}$ & 4.327 & 0.000 \\
& A2B1 & -7.77 & 4.327 & 0.297 \\
& A2B2 & -1.11 & $\mathbf{4 . 3 2 7}$ & $\mathbf{0 . 9 9 4}$ \\
\hline \multirow{4}{*}{ A2B1 } & A1B1 & $-13.8750^{*}$ & 4.327 & 0.017 \\
& A1B2 & 7.77 & 4.327 & 0.297 \\
& A2B2 & $\mathbf{6 . 6 6}$ & $\mathbf{4 . 3 2 7}$ & $\mathbf{0 . 4 2 9}$ \\
\hline \multirow{2}{*}{ A2B2 } & A1B1 & $-20.5350^{*}$ & 4.327 & 0.000 \\
& A1B2 & 1.11 & 4.327 & 0.994 \\
& A2B1 & -6.66 & 4.327 & 0.429 \\
\hline
\end{tabular}

Based on observed means.

The error term is Mean Square(Error) $=74.894$

*. The mean difference is significant at the .05 level.

The Differences learning outcomes in ICT among the students that using blended learning strategy $(B L S)$ and expository learning strategies (ELS).

Based on calculation of ANOVA (in Table 2) at the source of the variance between $\mathrm{A}$ denotes that the price of $F_{\text {cal }}$ is $4,351>$ the price of $F_{\text {table }} 4,17$ on $\alpha=0.05$ $(30,1)$, Rejected $\mathrm{H}_{\mathrm{o}}$ and accepted $\mathrm{H}_{1}$, it means that there are differences in ICT learning outcomes between students taught with BLS and ELS. This result evidenced by the average of learning outcomes in groups of students taught with BLS $\mathrm{Y}_{\mathrm{A} 1}=75.48$ and groups of students taught with ELS $Y_{\mathrm{A} 2}=69.09$. Thus, the learning outcomes of ICT students who are taught with BLS are higher than ELS.

The Differences learning outcomes in ICT among the students that having high creative thinking (HCT) and low creative thinking (LCT).

Based on the result of ANOVA calculation (Table 2) on source of variance between $B$ shows that $F_{\text {cal }}$ equal to $21,39>\mathrm{F}_{\text {table }}$ price equal to 4,17 at $\alpha=0.05, \mathrm{H}_{0}$ is rejected, and $\mathrm{H}_{1}$ accepted, it means there is difference of ICT learning result between student having HCT and LCT. On the other hand, the acquisition of the results of the learning group of students who have HCT has an average $\mathrm{Y}_{\mathrm{B} 1}=79.36$ is greater than the achievement of learning outcomes of the group of students who have LCT with the average $\mathrm{Y}_{\mathrm{B} 2}=65.21$. Thus, the result of ICT students learning outcomes that has HCT is better than those with LCT.

The Interaction between learning strategy and creative thinking to the result of learning of ICT (has an interaction effect).

Based on the calculation of ANOVA (Table 2) on the source of interaction variance $\mathrm{A} \times \mathrm{B}$ shows that the price $\mathrm{F}_{\text {cal }}=5.996>\mathrm{F}_{\text {table }}=4.17$ at $\alpha=0.05, \mathrm{H}_{0}$ is rejected and $\mathrm{H}_{1}$ accepted. This means that learning strategies has an effect on ICT learning outcomes depending on creative thinking and vice versa.

Differences in learning outcomes of ICT students are taught using BLS and ELS, in students who have HCT (simply effect).
Tukey test results in Table 3 for A1B1 with A2B1 obtained Sig. value $0,017<0.05, \mathrm{H}_{0}$ rejected and $\mathrm{H}_{1}$ accepted, with value $\mathrm{Y}_{(\mathrm{A} 1 \mathrm{~B} 1)}=86,3>\mathrm{Y}_{(\mathrm{A} 2 \mathrm{~B} 1)}=72,42$, thus, the result of learning of ICT students that use BLS is higher than the value of student learning outcomes using ELS in students who have HCT.

The differences of the students are taught by using BLS and ELS, in students who have LCT (simple effect).

Based on the results of further tests with Tukey test in Table 3 for A1B2 with A2B2 obtained Sig value $0.994>0.05, \mathrm{H}_{0}$ rejected and $\mathrm{H}_{1}$ accepted so there is no significant differences in learning outcomes of ICT students using BLS and ELS on students that have LCT. On the other hand, though the average value of $\mathrm{Y}_{(\mathrm{A} 1 \mathrm{~B} 2)}=$ $64.65<\mathrm{Y}_{(\mathrm{A} 2 \mathrm{~B} 2)}=65.76$, but in statistically the difference is meaningless. Thus, it can be concluded that there is no differences in ICT learning outcomes of students who are taught with BLS and ELS, for students who have LCT tendencies.

The Differences in ICT learning outcomes of students who have a tendency to think creatively high and low, on students who are taught by BLS.

Further test results with Tukey test in Table 3 for A1B1 with A1B2 obtained Sig $0,000<0.05, \mathrm{H}_{0}$ rejected and $\mathrm{H}_{1}$ accepted, with value $\mathrm{Y}_{(\mathrm{A} 1 \mathrm{~B} 1)}=86.3>\mathrm{Y}_{(\mathrm{A} 1 \mathrm{~B} 2)}=$ 64.65, therefore, ICT students who have HCT and LCT who are taught with BLS have differences.

Differences in ICT learning outcomes of students who have a tendency to think creatively high and low, students that are taught by ELS.

Further test results with Tukey test in Table 3 for A2B1 with A2B2 obtained Sig. value $0.429>0.05, \mathrm{H}_{0}$ accepted and $\mathrm{H}_{1}$ rejected, with value $\mathrm{Y}_{(\mathrm{A} 2 \mathrm{~B} 1)}=72,42>\mathrm{Y}$ ${ }_{\text {(A2B2) }}=65,76$, average A2B1> A2B2, but statistically not as significantly different, thus the ICT learning outcomes of students who have HCT and LCT taught by ELS have no differences.

\section{Conclusion}

Based on the results of this research can be drawn conclusions as follows: (1) Results of ICT learning of students who use BLS is higher than the ELS. Therefore, BLS can give better impact for improvement of students' ICT learning result; (2) there is an interaction between learning strategies and creative thinking toward ICT learning outcomes. Thus, the result of ICT learning of students who are taught by BLS are different in students who have HCT it means, learning strategies and creative thinking are two factors that determines the learning outcomes of ICT; (3) ICT learning outcomes of students using BLS is higher than ELS, in students who have HCT. Thus, the learning strategy for students who have HCT that has been using ELS can be replaced by using BLS; and (4) ICT learning outcomes of students using ELS have no differences in students who have HCT and LCT. Thus, an ELS can be used for students who have HCT and LCT. 


\section{References}

[1] Ace Suryadi. 2014. Pendidikan Indonesia Menuju 2025-Outlook : Permasalahan Tantangan \& Alternatif Kebijakan, Bandung : PT Remaja RosdaKarya. pp. 20J.

[2] Bernie Trilling \& Charles Fadel. 2009. 21 $1^{\text {st }}$ Century Skills : Learning for Life in Our Times, San Francisco : Jossey-Bass, pp. 45-84.

[3] Thorne, K. 2003. Blended Learning : How to Integrate Online and Traditional Learning, London : Kogan Page.

[4] Bruce Joyce, Marsha Weil, dan Emily Calhoun. 2009. Models of Teaching, New York : Pearson Education, Inc., pp. 369.

[5] Djalaluddin Rahman. 1996. Psikologi Komunikasi, Bandung : PT Remaja Rosda Karya, pp. 74-76.

[6] Kadir. 2015. Statistika Terapan : Konsep, Contoh, dan Analisis Data dengan Program SPSS/Lisrel dalam Penelitian. Jakarta : Rajawali Pers.

[7] Glass, R.V., Hopkins, K.D. 1984. Statistical Methods in Education and Psychology $2^{\text {nd }}$ Edition. New Jersey: Prentice-Hall, Inc., pp. 371.

[8] Sudjana. 2005. Metode Statistika. Bandung: Tarsito, pp.330-337.

[9] Agung, IG. N. 2006. Statistika Penerapan Model Rerata- Sel Multivaria dan Model Ekonometrika dengan SPSS. Jakarta: Yayasan Sad Satria Bhakti, pp. 284. 